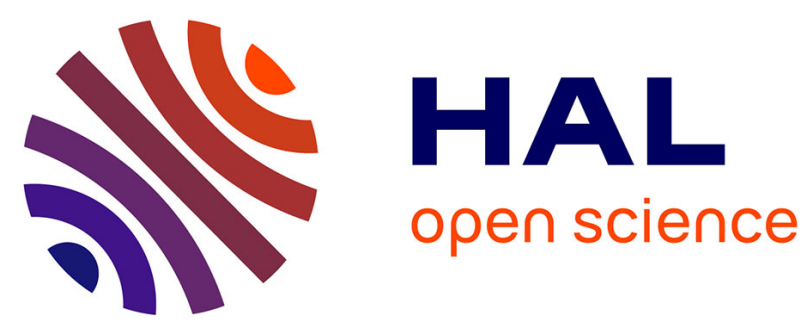

\title{
Microbial consortia in an ice-covered high-altitude lake impacted by additions of dissolved organic carbon and nutrients
}

Flavia Dory, Laurent Cavalli, Evelyne Franquet, B. Misson, Thierry Tatoni, Céline Bertrand, Magalie Claeys-Bruno

\section{To cite this version:}

Flavia Dory, Laurent Cavalli, Evelyne Franquet, B. Misson, Thierry Tatoni, et al.. Microbial consortia in an ice-covered high-altitude lake impacted by additions of dissolved organic carbon and nutrients. Freshwater Biology, 2021, 66 (8), pp.1648-1662. 10.1111/fwb.13781 . hal-03375780

\section{HAL Id: hal-03375780 \\ https://hal-amu.archives-ouvertes.fr/hal-03375780}

Submitted on 10 Jan 2022

HAL is a multi-disciplinary open access archive for the deposit and dissemination of scientific research documents, whether they are published or not. The documents may come from teaching and research institutions in France or abroad, or from public or private research centers.
L'archive ouverte pluridisciplinaire HAL, est destinée au dépôt et à la diffusion de documents scientifiques de niveau recherche, publiés ou non, émanant des établissements d'enseignement et de recherche français ou étrangers, des laboratoires publics ou privés. 


\title{
Microbial consortia in an ice-covered high-altitude lake impacted by additions of dissolved organic carbon and nutrients
}

\author{
Flavia Dory ${ }^{1}$ (D) | Laurent Cavalli ${ }^{1}$ (D) | Evelyne Franquet ${ }^{1}$ (D) | Magalie Claeys-Bruno ${ }^{1}$ (D) | \\ Benjamin Misson $^{2}$ (D) | Thierry Tatoni ${ }^{1}$ (D) | Céline Bertrand ${ }^{1}$ (iD
}

${ }^{1} \mathrm{CNRS}$, IRD, IMBE, Aix Marseille Univ, Avignon Université, Marseille, France

${ }^{2} \mathrm{CNRS}$, IRD, MIO, Aix Marseille Univ, Université de Toulon, Toulon, France

\section{Correspondence}

Flavia Dory, CNRS, IRD, IMBE, Aix Marseille Univ, Avignon Université, Marseille, France.

Email: flavia.dory@imbe.fr

Funding information

Ministère de l'Enseignement Supérieur et de la Recherche

\section{Abstract}

1. High-altitude lakes are sentinels of change. Anticipated increases in inputs of dissolved organic carbon (DOC) from catchments in high-altitude lakes could affect planktonic interactions, especially if inputs occur during the winter ablation phase. However, the responses of plankton communities to added DOC interacting with nutrients during this period are still not well understood.

2. We sampled under-ice water and used a multifactorial experimental design to investigate the DOC effect on planktonic organisms (phytoplankton and heterotrophic prokaryotic plankton [HPP]) and their interactions during the winter ablation phase. The plankton community was subjected to DOC additions $(0,2,4$, and $6 \mathrm{mg} \mathrm{C/L}$ ) under two nutrient-availability treatments (natural concentrations or enriched in $\mathrm{N}$ and $\mathrm{P}$ ), two light conditions (dark or light), and two temperature conditions $\left(10\right.$ or $\left.18^{\circ} \mathrm{C}\right)$.

3. We found HPP to be co-limited by N, P, and C in our microcosms. Added glucose as available C-source for bacterioplankton was highly consumed at the end of the experiments. This consumption was not always related to an increase of the HPP biomass, due to a rising predatory control by ciliates and mixotrophic phytoplankton over bacteria. In dark conditions, the biomasses of both autotrophic and mixotrophic phytoplankton were substantially reduced, and the HPP biomass under DOC and nutrient additions principally depended on the predatory control exerted by ciliates. In light conditions, a diversification of top-down control over bacteria was observed, with the HPP response to DOC and nutrient additions depending on both mixotrophs and ciliates. Moreover, when heterotrophic ciliates and mixotrophs were present together in the experiments, the ciliates replaced the mixotrophs in phagotrophy over bacteria.

4. Our experimental results indicate that DOC inputs can rapidly alter the trophic interactions of the planktonic food web, depending on nutrient limitation in highaltitude lakes. We found decreased commensalistic interactions between bacteria and phytoplankton, but increased competition and predation, after DOC additions. 
5. The expected future scenario of global change during the ablation phase is likely to change the balance between heterotrophic and autotrophic processes in planktonic food webs by increasing heterotrophic processes. These changes could have major repercussions on energy transfer from the base to the top of the food chain in high-altitude lakes.

6. Exploring the planktonic response to rapid environmental changes during the ablation phase appears to be crucial in order to determine how vulnerable high-altitude lakes are to future change.

\section{KEYWORDS}

glucose addition, heterotrophic bacteria, mixotrophy, nutrient co-limitation, trophic interactions

\section{1 | INTRODUCTION}

Oligotrophic high-altitude lakes have been identified as sentinels of change (Moser et al., 2019; Williamson et al., 2009) and provide ideal ecosystems for studying the impacts of global change on biodiversity. Lakes in the alpine region are undergoing change driven by climate and anthropogenic factors (Smiatek et al., 2016). It has been found that atmospheric nutrient deposition of nitrogen $(\mathrm{N})$ and phosphorus $(\mathrm{P})$ is intercepted by mountain catchments (Battarbee et al., 2009), altering the nutrient limitations in alpine lakes (Bergström et al., 2008; Elser et al., 2009). Furthermore, the Alps have a particularly high warming rate: since the late 19 th century, they have warmed twice as fast as the global or Northern Hemispheric average (Auer et al., 2007). Models of climate change also predict increasing extreme precipitation events in the alpine region during the current century (IPCC, 2013). Both the current upward shift of the treeline in alpine regions and the predicted increase in extreme precipitation events could substantially increase inputs to lakes from terrestrial runoff, including dissolved organic carbon (DOC; Ejarque et al., 2018; Moser et al., 2019).

Increased allochthonous concentrations of DOC have been shown to seriously affect the planktonic food web functioning in aquatic systems. Inputs of allochthonous DOC fuel bacterial respiration and production (Soares et al., 2018), and reduce bacterial reliance on phytoplankton-produced carbon, particularly in oligotrophic, carbon-limiting ecosystems (Medina-Sánchez et al., 2004). High quantities of DOC modify bacterial limitation toward a primary limitation by nitrogen (N) and phosphorus (P; Pinhassi et al., 2006), leading to direct competition with phytoplankton for these nutrients (Carney et al., 2016; Hitchcock \& Mitrovic, 2013). Plankton communities dominated by bacteria are thus typically found in lakes with high inputs of allochthonous DOC (Jansson et al., 2000; Karlsson, 2001). Mixotrophic phytoplankton acquire carbon and/or mineral nutrients from bacterial prey, which allows them to eliminate their main competitors for these nutrients (Thingstad et al., 1996). Increased DOC concentrations therefore have the potential to directly alter the phytoplankton species assemblage by favouring mixotrophic flagellates relative to autotrophs when the plankton community is dominated by bacteria (Jansson et al., 1999).

Interactions between DOC and nutrients alter the net impact of DOC on aquatic systems (Hitchcock et al., 2010). Several studies have reported a nutrient and carbon co-limitation in heterotrophic bacteria, leading to synergetic responses when resources were added concomitantly rather than separately (Dorado-García et al., 2014; Egli \& Zinn, 2003). However, inorganic nutrients associated with dissolved organic matter may also stimulate primary productivity through enhanced nutrient availability (Deininger et al., 2017; Kissman et al., 2017). The generally low concentration of DOC in oligotrophic high-altitude lakes (commonly $<1 \mathrm{mg} / \mathrm{L}$, see Laurion et al., 2000) makes these ecosystems highly sensitive to increased DOC inputs (Sadro \& Melack, 2012). Thus, bacteria were found to depend strongly on photosynthetic labile carbon released by algae, i.e. commensalistic interactions, in high-altitude lakes (GonzálezOlalla et al., 2018; Medina-Sánchez et al., 2004). However, little is known about the effects on planktonic organisms of a labile carbon source and its interactions with nutrients in high altitude lakes, especially during the ablation phase of the ice-cover period.

In alpine regions, ice cover is a recurrent and prolonged state for lakes, acting as a major physical control on ecosystems (Moser et al., 2019; Pernica et al., 2017). Felip et al. (2002) distinguish three phases of winter cover: formation, growth, and ablation. Ablation is influenced by water melting from the snowpack in the catchment, correlated with nutrient loading rates and availability in lakes (Leydecker et al., 2001). Dissolved organic matter of terrestrial origin and a predominantly heterotrophic epilimnion were thus observed immediately after snowmelt in a high-altitude lake of the Sierra Nevada (Sadro \& Melack, 2012). Global change, by affecting the quantity of accumulated snow and the nutrient quality and quantity in the catchment snowpack, could have direct repercussions on ecosystem functioning in these lakes (Sadro et al., 2018).

The under-ice plankton communities of high-altitude lakes can tell us a lot about the effects of inputs of DOC and nutrients. Firstly, plankton communities experience the impact of inputs from the catchment and atmospheric deposition during snowmelt. Secondly, 
under-ice communities should be composed of taxa adapted to more heterotrophic conditions and should therefore show a clear response to DOC inputs. Finally, these communities constitute the inoculum of summer phytoplankton succession (Adrian et al., 1999), so that changes in community structure could significantly impact the biodiversity of high-altitude lakes. However, a clearer picture is needed of how increased allochthonous inputs during the ablation period alter the functioning of high mountain lakes, especially the trophic relationships between phytoplankton and bacterioplankton.

This study investigated a plankton community's response to DOC inputs in interaction with inorganic nutrients during the ablation phase of the ice-covered period. We sampled the natural plankton assemblage under ice in a high-altitude lake and placed it under a dark: light cycle at $10^{\circ} \mathrm{C}$ in laboratory microcosms. Then we subjected it to DOC additions under two nutrient-availability conditions (ambient concentrations or enriched by $\mathrm{N}$ and $\mathrm{P}$ ). Glucose was used as DOC because it is a readily available $\mathrm{C}$-source for bacterioplankton. To clarify the phytoplankton-bacterioplankton relationship, a total darkness treatment was realised to target heterotrophic processes, and an $18^{\circ} \mathrm{C}$ treatment was realised to accelerate the metabolic processes of planktonic organisms. We hypothesised that: (1) under dark conditions limiting the influence of autotrophs, the addition of DOC should favour heterotrophic bacteria and mixotrophic phytoplankton; and (2) under light conditions, the addition of DOC should have a negative effect on autotrophs but a positive effect on heterotrophic prokaryotic plankton (HPP) and mixotrophs due to competition for nutrients.

\section{2 | METHODS}

\section{1 | Water sampling for experiments}

Water for experiments was sampled in Lake Cordes, a high mountain lake located in the French Alps, adjacent to the Queyras regional nature park (France, 44 $50^{\prime} 42^{\prime \prime} \mathrm{N}, 6^{\circ} 47^{\prime} 20^{\prime \prime} \mathrm{E}$ ). Lake Cordes is situated above the treeline at $2,446 \mathrm{~m}$ above sea level. The lake is small (1.8 ha) and shallow (maximum depth $=9 \mathrm{~m}$ ). The catchment area is large (140 ha), consisting of developed soils and meadows with approximately $60 \%$ alpine grass cover. The catchment lithology is mainly metamorphic rock (blue Shales). This lake has been described as oligotrophic by Jacquemin et al. (2018), with strong limitation of phytoplankton by $\mathrm{N}$ and $\mathrm{P}$. The lake is ice-covered for 7-8 months, from October to June.

Sampling was conducted on 26th April 2019, at the transition from the growth to the ablation phase, when ice cover is usually at maximum thickness (Catalan et al., 2006). The lake was reached by ski and the water sampled for experiments by drilling a hole in the snow and in the ice. Water samples totalling $30 \mathrm{~L}$ were collected using a Niskin Bottle every metre, in order to sample the entire water column. The sampled water was filtered through a 50- $\mu \mathrm{m}$ mesh to exclude larger potential grazers on food web components. This filtered water was then stored in sterilised opaque HDPE 8-L containers, placed in a cool box, and transported to the laboratory as soon as possible (between 5 and $6 \mathrm{hr}$ later).

\section{2 | Experimental design}

\subsection{1 | Factors and domain of interest}

The aim of this study was to evaluate the effects of DOC and nutrient additions on a plankton community during the ablation phase in a high-altitude lake, particularly on interactions between heterotrophic bacteria and phytoplankton. To explore under-ice phytoplankton community responses, four factors were investigated:

- DOC additions (four treatments): 0, 2, 4, and $6 \mathrm{mg} \mathrm{C/L}$, coded respectively $[0 \mathrm{C}],[2 \mathrm{C}],[4 \mathrm{C}]$ and $[6 \mathrm{C}]$.

For the DOC additions, glucose was chosen as the carbon source to ensure that only the influence of the available fraction of DOC inputs was tested. Glucose is commonly used as a source of DOC in other similar microcosm experiments (Hitchcock et al., 2010; Liao et al., 2019). It was added in relatively low concentrations $(+2,+4$, and $+6 \mathrm{mg} / \mathrm{L}$ ) consistent with theoretical values for the biodegradable DOC fraction transported into the lake during the ablation period, but sufficient to ensure that, gradually, higher than natural DOC concentrations were reached. The $0 \mathrm{C}$ treatments with no glucose addition were used as the DOC-control, for comparison with the DOC additions.

- Nutrient addition (two treatments): ambient-nutrient concentration [ONP] and nitrogen and phosphorus-enriched [NP].

For the nutrient addition, $\mathrm{N}$ was added as $\mathrm{NH}_{4} \mathrm{NO}_{3}$ to increase $\mathrm{N}$ concentrations to $335 \mu \mathrm{g} / \mathrm{L}$ and $\mathrm{P}$ was added as $\mathrm{KH}_{2} \mathrm{PO}_{4}$ to increase $\mathrm{P}$ concentrations to $35 \mu \mathrm{g} / \mathrm{L}$. The aim was to avoid potential nutrient limitation throughout this experiment, while remaining consistent with natural concentrations of dissolved inorganic nitrogen (DIN) and soluble reactive phosphorus (SRP) (Jacquemin et al., 2018).

- Temperature (two conditions): $\left[10^{\circ} \mathrm{C}\right]$ and $\left[18^{\circ} \mathrm{C}\right]$

The $10^{\circ} \mathrm{C}$ temperature was chosen in order to mimic the conditions prevailing at the end of the ablation phase (a surface temperature of $2.79^{\circ} \mathrm{C}$ was measured on 9 June 2016 in Lake Cordes, subsequently reaching $10.27^{\circ} \mathrm{C}$ on 24 June 2016 , personal data). The $18^{\circ} \mathrm{C}$ temperature was chosen to enhance heterotrophy and accelerate the metabolic processes of organisms, without representing a threat to the planktonic organisms (Jacquemin, 2019).

- Light conditions (two conditions): total darkness [Dark] and light: dark cycle [Light]. 
The dark condition was intended to target heterotrophic processes while minimising the influence of autotrophs. For the dark condition, microcosms were placed in the dark in growth chambers, surrounded by aluminium. The light condition was designed to mimic light conditions at the end of the ablation phase, after ice-out. For the light condition, microcosms were placed under a circadian cycle (Light: dark cycle $=14: 10)$, at a fixed irradiance $\left(45 \pm 2 \mu \mathrm{mol} \mathrm{m} \mathrm{m}^{-2} \mathrm{~s}^{-1}\right)$. This irradiance was sufficient to avoid light limitation in the microcosms (Dubourg et al., 2015; Jacquemin et al., 2018).

\subsection{2 | Design of experiments}

The experimental designs are mathematical and statistical techniques that optimise the relevance of the data obtained by quantifying the relationship between output and input variables (Box et al., 1978; Montgomery, 2017), while reducing the number of experiments required. Contrary to a one-factor-at-a-time approach, the experimental design involves simultaneous variation of all the factors, with a subset of combinations of experiments selected for modelling to estimate the effects of the four factors by considering the interactions between them. This approach, which is widely used in chemical studies, is relatively innovative in ecology.

The aim of this study was to evaluate the influence of DOC addition through interaction effects, i.e. quantifying a change in the effect of one factor according to the value of another factor. We considered the result of each experiment to be a linear combination of the main effects and interaction effects of each dimensionless factor, only taking into account interactions between two factors. This model could be written as:

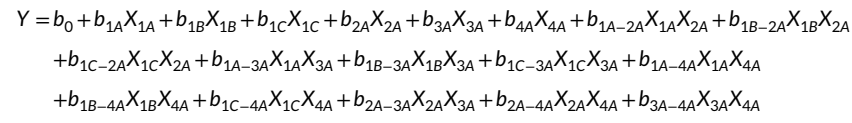

$X 1=$ DOC, $X 2=$ Nutrients, $X 3=$ Light, $X 4=$ Temperature, $b 0=$ model constant, $b_{i A \ldots C}=$ coefficients for single and interactive effects.

To estimate the coefficients of this linear model, we used a Doptimal design with 24 experiments, which is a subset of the experiments under the full $4^{*} 2 * 2 * 2$ factorial design with 32 experiments. The linear model was also used to predict the output values for the eight conditions not treated experimentally. The 32 experiments ( 24 treated experimentally and eight modelled) are interpreted together in our study. All 24 experiments were realised in triplicate, for a total of 72 experiments (Table S1). Each experiment is a combination of one carbon treatment, one nutrient treatment, one temperature condition, and one light condition. The experimental design made it possible to reduce the number of experiments experimentally realised, thereby reducing the quantity of water transported from the lake. All quantitative analyses were realised with the AZURAD software (version Expert, AZURAD SAS, Marseille, France. 2019).

\subsection{3 | Experimental set-up}

Plankton were first acclimatised overnight in three 10-L sterilised transparent polycarbonate plastic bottles (Nalgene ${ }^{\circledR}$ ) at $10^{\circ} \mathrm{C}$ under the circadian cycle before the start of the experiments. Then, water from each polycarbonate plastic bottle was manually homogenised and transferred to the 72 microcosms. Each microcosm consisted of a $500-\mathrm{ml}$ sterilised transparent polycarbonate plastic bottle $\left(\right.$ Nalgene ${ }^{\circledR}$ ) filled with $350 \mathrm{ml}$ of sampled water to allow gas exchanges, according to the protocol used by Jacquemin et al. (2018). Natural planktonic organisms were incubated under the different experimental conditions for 10 days. The microcosms were manually homogenised and randomly displaced inside the growth chamber every day.

\section{3 | Measurements}

\subsection{1 | Dissolved organic carbon}

Dissolved organic carbon was measured at the initial conditions and at the end of the experiments. Subsamples were filtered through pre-combusted 25-mm diameter glass filters (Whatman GF/F, $0.7 \mu \mathrm{m})$, then stored in $24 \mathrm{ml}$ pre-combusted $\left(4 \mathrm{hr}\right.$ at $\left.450^{\circ} \mathrm{C}\right)$ glass tubes (Wheaton equipped with Teflon/silicone septa) and preserved with $30 \mu$ of sodium azide solution $\left(1 \mathrm{M} \mathrm{NaN}_{3}\right)$ at $+4^{\circ} \mathrm{C}$. DOC concentration was determined using a TOC-VCSH analyser (Shimadzu, TOC-V). Consumed DOC was the difference between the initial DOC concentrations after carbon additions and the final DOC concentrations measured at the end of the experiments.

\subsection{2 | Anions and cations}

Subsamples of water were filtered through precombusted 25$\mathrm{mm}$ glass filters (Whatman GFF, $0.7 \mu \mathrm{m}$ ) for estimation of DIN $\left(\mathrm{DIN}=\mathrm{NH}_{4}^{+}+\mathrm{NO}_{2}^{+} \cdot \mathrm{NO}_{3}^{2-}\right)$ and SRP $\left(\mathrm{SRP}=\mathrm{PO}_{4}^{3-}\right)$ concentrations at the initial conditions. The dissolved fraction was stored in a 125$\mathrm{ml}$ HDPE bottle, placed in a cool box and frozen $\left(-18^{\circ} \mathrm{C}\right)$ until analysis. Dissolved anions and cations were determined by ionic chromatography (Metrohm, 930 Compact IC Flex combined with 863 Compact Autosampler).

\subsection{3 | Chlorophyll a}

Chlorophyll a concentration was measured at the initial conditions and at the end of the experiments to estimate chlorophyll biomass. Water was filtered through 47-mm glass filters (Whatman GF/C, $1.2 \mu \mathrm{m}$ ) placed in glass tubes filled with $10 \mathrm{ml}$ of acetone solution (90\%) for $24 \mathrm{hr}$ at $+4^{\circ} \mathrm{C}$ for chlorophyll a extraction. Chlorophyll a concentrations were measured spectrophotometrically (Jasco, 
$\mathrm{V}$-630) by the Lorenzen method, with correction for pheophytin interference by acidification.

\subsection{4 | Phytoplankton}

Our analyses distinguished between picophytoplankton $(<2 \mu \mathrm{m}$ size) and larger phytoplankton ( $>2 \mu \mathrm{m}$ size), for a finer assessment of trophic functioning (Izaguirre et al., 2020).

Sub-samples of $1.5 \mathrm{ml}$ were taken at the initial conditions and thereafter every 2 experimental days in the microcosms for picophytoplankton analyses by flow cytometry. Subsamples were fixed with glutaraldehyde $\left(0.25 \%\right.$ final concentration) and stored at $-80^{\circ} \mathrm{C}$ until flow cytometry analysis. Picophytoplankton were characterised and enumerated using an Accuri C6 flow cytometer equipped with a blue laser $(488 \mathrm{~nm})$ and running $500 \mu \mathrm{l}$ of sample at fast speed $(66 \mu \mathrm{l} /$ min). Data were acquired and analysed using BD Accuri CFlow Plus Analysis software (BD-Biosciences). Picophytoplankton were identified according to size (FSC), complexity (SSC), and fluorescence (emission in the orange and red wavelength ranges, respectively $585 \pm 20$ and $>670 \mathrm{~nm}$ ). Non-fluorescent polystyrene microspheres (Flow Cytometry Size Calibration Kit, Thermo Fisher Scientific) were used as a size standard. Flow cytometer analysis distinguished between two picophytoplankton groups. Small cells $(<2 \mu \mathrm{m})$ with high orange fluorescence and low granularity were classified as phycoerythrinrich picocyanobacteria (picocyanobacteria). A picoeukaryote group was identified by its high red and low orange fluorescence, small size $(<2 \mu \mathrm{m})$ but higher granularity than the picocyanobacteria.

Phytoplankton $>2 \mu \mathrm{m}$ in size were enumerated and identified via microscopy. Phytoplankton communities were analysed before the start and at the end of the experiments. The samples for phytoplankton composition analysis were fixed with alkaline Lugol solution $(0.5 \%)$ and stored in $150 \mathrm{ml}$ HDPE bottles at $+4^{\circ} \mathrm{C}$. Phytoplankton counts were performed according to the Utermöhl (1958) method, at 40-fold magnification under an inverted microscope (Olympus IX 70). Phytoplankton samples were identified at genus level and species level when possible, using appropriate taxonomic guides.

To ensure that picocyanobacteria and cyanobacteria $>2 \mu \mathrm{m}$ were not double counted, we calculated the average size of each of these groups. We estimated the mean size of picocyanobacteria from the average FSC value of their cytometric population. We then used the equation obtained from the linear regression between the size of polystyrene microspheres (Flow Cytometry Size Calibration Kit, Thermo Fisher Scientific) and their respective FSC values. For the unicellular cyanobacteria $>2 \mu \mathrm{m}$, we measured the length of each cell $(n>30)$ using NIS Element ${ }^{\circledR}$ software, then calculated an average length for the group.

\subsection{5 | Heterotrophic prokaryotic plankton}

Sub-samples of $1 \mathrm{ml}$ were taken at the initial conditions and thereafter every 2 experimental days in the microcosms for HPP analyses by flow cytometry. Subsamples were fixed with glutaraldehyde ( $0.25 \%$ final concentration) and stored at $-80^{\circ} \mathrm{C}$ until flow cytometry analysis. After thawing, each sample was stained with 1:10,000 (vol/vol) SYBR ${ }^{\circledR}$ Green II and incubated 20 min in darkness. HPP were characterised and enumerated using an Accuri C6 flow cytometer equipped with a blue laser $(488 \mathrm{~nm})$ and running $50 \mu \mathrm{l}$ of stained sampled at medium speed $(35 \mu \mathrm{l} / \mathrm{min})$. Data were acquired and analysed using BD Accuri CFlow Plus Analysis software (BDBiosciences). HPP were identified by their small size (low FSC), low complexity (low SSC), high green fluorescence (530 $\pm 15 \mathrm{~nm}$ ), and lack of red $(>670 \mathrm{~nm}$ ) fluorescence.

\subsubsection{Cellular carbon biomass calculation}

To estimate the carbon biomass of the natural picoplankton organisms, abundance was transformed into carbon content based on the literature. Cell abundance (cells/ml) of HPP was converted to biomass ( $\mu \mathrm{g} \mathrm{C/L}$ ) using $20 \mathrm{fg} \mathrm{C/cell} \mathrm{as} \mathrm{constant} \mathrm{conversion} \mathrm{factor}$ (Ducklow, 2000; Linacre et al., 2015). The conversion factor for picocyanobacteria was $237 \mathrm{fg} \mathrm{C/cell} \mathrm{(Gerea} \mathrm{et} \mathrm{al.,} \mathrm{2019)} \mathrm{and} \mathrm{for}$ picoeukaryotes it was $56 \mathrm{fg} \mathrm{C/cell} \mathrm{(Linacre} \mathrm{et} \mathrm{al.,} \mathrm{2015).} \mathrm{For} \mathrm{phy-}$ toplankton $>2 \mu \mathrm{m}$, biovolume was estimated by shape assimilation to known geometric forms and direct measurement of the main cell dimensions. The mean biovolume was calculated for each class of phytoplankton, then the biovolume was converted into biomass using the particular carbon content defined for each class by Wetzel and Likens (2000).

\subsection{7 | Ciliate abundance estimations}

We attempted here to minimise any possible predation by multicellular zooplankton and ciliates by filtering the water at $50 \mu \mathrm{m}$. However, to determine whether any predators had developed in our microcosms, ciliate abundances were estimated via the Utermöhl method (Felip et al., 2002), under initial conditions and at the end of the experiments.

\subsection{Statistical analysis}

\subsection{1 | Quantitative analysis}

The effect of DOC additions in interaction with nutrients, with temperature, and with light was tested using the linear model estimated according to the experimental design. For each output variable, the coefficients of the model were calculated (version Expert, AZURAD SAS, Marseille, France. 2019) using multilinear regressions (see Section 2.2.2). For the eight modelled experiments, data were calculated using the model and the error bars were calculated based on the mean standard errors of the 24 triplicates, with a $95 \%$ confidence interval. 


\subsection{2 | Multivariate analysis}

Multivariate analyses to detect changes in phytoplankton community structure were performed on the phytoplankton biomass at the end of the experiment. Multivariate analyses were performed with the vegan package on $\mathrm{R}$ software (v. 3.6.3). Because phytoplankton community structure differed strongly between the dark and the light conditions, all multivariate analyses were performed twice, under both dark and light conditions. To visualise the differences in phytoplankton community structure between treatments, we performed a non-metric multidimensional scaling analysis on the Bray-Curtis dissimilarity matrix to depict community structure patterns in two dimensions. To test the hypothesis that DOC addition structured the distribution of phytoplankton communities, permutational multivariate analysis of variance (PERMANOVA) was used with 999 permutations $(p=0.05)$ with the ADONIS function in R. We carried out a multivariate homogeneity of group dispersion analysis ( $\beta$ diversity) to assess the homogeneity of phytoplankton assemblages within a group of samples (Anderson et al., 2006). A similarity percentage (SIMPER) analysis was performed to identify which phytoplankton groups govern community dynamics.

\section{3 | RESULTS}

\section{1 | Initial conditions}

Chemical variables such as DOC, SRP, and DIN were low at the start of the experiments, representative of typical oligotrophic lakes with $\mathrm{C} / \mathrm{N}$ ratio $=2.5$ (Table 1 ). Plankton biomass was dominated by HPP at the start of the experiments, but phytoplankton biomass showed a value relatively close to that of HPP biomass. Phytoplankton biomass was dominated by large diatoms such as Fragilaria sp. (32\%), picocyanobacteria (25\%), chrysophytes-mainly Dinobryon sp.-(19\%), and dinoflagellates (15\%). Unicellular cyanobacteria $>2 \mu \mathrm{m}$ also represented a non-negligible proportion of the phytoplankton biomass.

\subsection{Consumed DOC at the end of experiments}

The DOC consumed at the end of the experiments varied according to DOC interaction with nutrients $(p<0.001)$, with temperature $(p<0.001)$, or with light $(p<0.001)$. DOC consumed increased according to the glucose gradient in almost all the four conditions of temperature*light (Figure 1). In DOC-control treatments (OC), DOC was consumed in the dark but was in excess in the light at the end of the experiments, whatever the temperature. However, DOC was consumed more when glucose was added at $18^{\circ} \mathrm{C}$ than at $10^{\circ} \mathrm{C}$, whatever the light condition. Finally, DOC was consumed more when glucose was added in combination with nutrient addition (NP) than in nutrient-ambient treatments (ONP).
TABLE 1 Mean values of the main chemical and biological variables measured in the initial experimental conditions

\begin{tabular}{|c|c|}
\hline Variable & $\begin{array}{l}\text { Mean } \\
\text { values } \pm S D\end{array}$ \\
\hline $\operatorname{SRP}(\mu g / L)$ & $5 \pm 2$ \\
\hline DIN (mg/L) & $0.27 \pm 0.03$ \\
\hline $\mathrm{DOC}(\mathrm{mg} / \mathrm{L})$ & $0.69 \pm 0.12$ \\
\hline HPP biomass ( $\mu \mathrm{g} C / L)$ & $17.73 \pm 1.19$ \\
\hline Chlorophyll biomass ( $\mu \mathrm{g} / \mathrm{L}$ ) & $1.01 \pm 0.09$ \\
\hline Phytoplankton biomass ( $\mu \mathrm{g} \mathrm{C} / \mathrm{L}$ ) & $14.79 \pm 2.82$ \\
\hline Diatoms ( $\mu \mathrm{g} \mathrm{C} / \mathrm{L}$ ) & $4.70 \pm 0.60$ \\
\hline Chlorophytes ( $\mu \mathrm{g} \mathrm{C} / \mathrm{L}$ ) & $0.18 \pm 0.07$ \\
\hline Streptophytes ( $\mu \mathrm{g} \mathrm{C} / \mathrm{L}$ ) & $0.00 \pm 0.00$ \\
\hline Chrysophytes ( $\mu \mathrm{g}$ C/L) & $2.83 \pm 0.92$ \\
\hline Cryptophytes ( $\mu \mathrm{g}$ C/L) & $0.39 \pm 0.19$ \\
\hline Dinoflagellates ( $\mu \mathrm{g} C / L)$ & $2.21 \pm 0.60$ \\
\hline Cyanobacteria $>2 \mu \mathrm{m}(\mu \mathrm{g} \mathrm{C/L})$ & $0.69 \pm 0.17$ \\
\hline Picocyanobacteria ( $\mu \mathrm{g} \mathrm{C} / \mathrm{L})$ & $3.77 \pm 0.24$ \\
\hline Picoeukaryotes ( $\mu \mathrm{g} \mathrm{C} / \mathrm{L}$ ) & $0.01 \pm 0.001$ \\
\hline Ciliate abundance (cell/ml) & $0.00 \pm 0.00$ \\
\hline
\end{tabular}

Abbreviations: DIN, dissolved inorganic nitrogen; DOC, dissolved organic carbon; HPP, heterotrophic prokaryotic plankton; SRP, soluble reactive phosphorus.

\section{3 | Heterotrophic prokaryotic plankton}

Interactions between DOC and nutrients ( $p=0.009)$, DOC and temperature $(p<0.001)$, and DOC and light $(p=0.017)$ had significant effects on HPP biomass assessed at the end of the experiments. Under the $10^{\circ} \mathrm{C}_{-}$dark condition, addition of DOC increased HPP biomass compared to DOC-control treatments (Figure 2). Under the $10^{\circ} \mathrm{C}$ _light condition, addition of DOC increased HPP biomass compared to DOC-control in the ambient-nutrient treatments. HPP biomass decreased with $\mathrm{DOC}$ addition compared to $O \mathrm{C}$ at $18^{\circ} \mathrm{C}$ _dark in the NP treatments, and at $18^{\circ} \mathrm{C}$ light in both the ONP and the NP treatments.

Moreover, interactions between nutrient addition and temperature affected HPP biomass $(p<0.001)$. At the end of the experiments, $\mathrm{N}$ and $\mathrm{P}$ additions increased HPP biomass at $10^{\circ} \mathrm{C}$ but not at $18^{\circ} \mathrm{C}$. However, nutrient addition had a positive effect on HPP biomass at $18^{\circ} \mathrm{C}$ as well, until the sixth day of the experiments (Figure 3 ; Table S2). This was followed by a strong decline in HPP biomass until the end of the experiments.

\section{4 | Ciliates}

Interactions between DOC and nutrients $(p=0.003)$, and DOC and temperature $(p<0.001)$ significantly affected ciliate abundance at the end of the experiments. Very few ciliates developed 

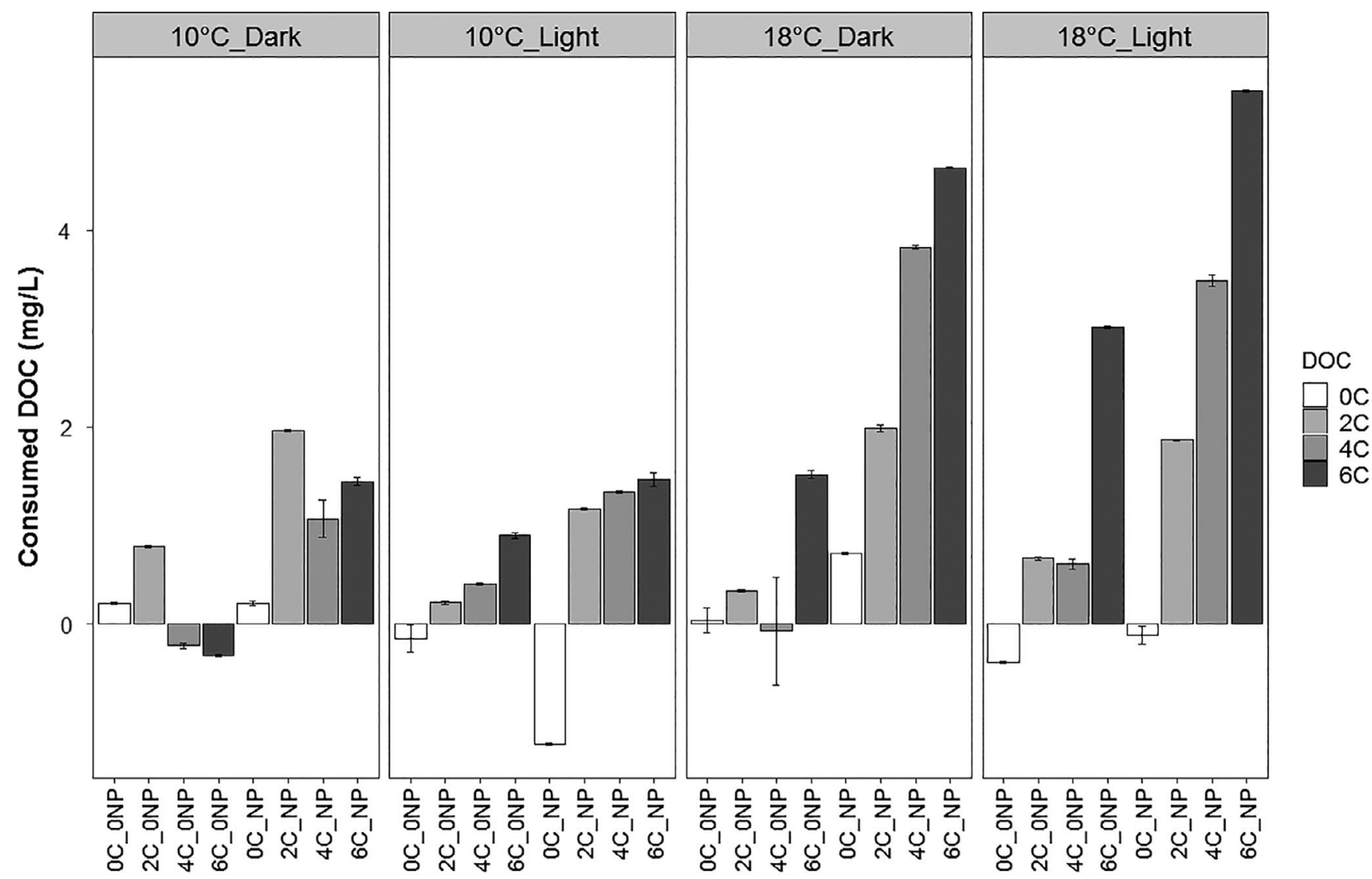

Treatments

FIGURE 1 Dissolved organic carbon (DOC) consumed at the end of each experiment. Concentrations are shown for each DOC*nutrient treatment under the four temperature*light conditions. Error-bars represent standard error $(n=3)$. High values indicate lower

concentrations at the end of the experiments than at initial conditions, while negative values indicate higher concentrations at the end of the experiments than at initial conditions

in the microcosms at $10^{\circ} \mathrm{C}$, regardless of light condition (Figure 4). However, ciliates developed at $18^{\circ} \mathrm{C}$ when DOC was added either alone or in combination with nutrients. A particularly strong increase in ciliate abundance was observed when DOC was added at concentrations of 4 and $6 \mathrm{mg} / \mathrm{L}\left(4 \mathrm{C}\right.$ and $6 \mathrm{C}$ ). At $18^{\circ} \mathrm{C}$, in the $4 \mathrm{C} \_N P$ and 6C_NP treatments, ciliate abundance was higher in the dark than in the light at the end of the experiments.

\section{5 | Chlorophyll biomass}

There were significant effects from interactions between carbon and nutrients $(p<0.001)$, carbon and temperature $(p<0.001)$, and carbon and light $(p<0.001)$ on chlorophyll biomass at the end of the experiments. In dark conditions, chlorophyll biomass was below the initial concentration of $1.01 \mu \mathrm{g} / \mathrm{L}$ in almost all treatments. The exceptions were the treatments at $10^{\circ} \mathrm{C}$ at $2 \mathrm{C}_{-} \mathrm{ONP}$ and $6 \mathrm{C}_{-} \mathrm{ONP}$, where chlorophyll biomass reached 1.52 and $1.31 \mu \mathrm{g} / \mathrm{L}$, and at $18^{\circ} \mathrm{C}$ at $0 \mathrm{C}_{-} \mathrm{NP}$, where chlorophyll biomass reached $1.89 \mu \mathrm{g} / \mathrm{L}$ (Figure 5). In light conditions, chlorophyll biomass increased more strongly in DOC-controls than under DOC additions, except at $10^{\circ} \mathrm{C}$ in the ONP treatments. This effect was more pronounced at $18^{\circ} \mathrm{C}$ in nutrient-enriched conditions, where chlorophyll biomass increased by $7.9 \mu \mathrm{g} / \mathrm{L}$ in the DOC-control but only between 4.5 and $5.1 \mu \mathrm{g} / \mathrm{L}$ after DOC additions.

Chlorophyll biomass was strongly correlated with final total phytoplankton biomass (Pearson's correlation, Cor $=0.91, p<0.001$ ).

\subsection{Shifts in phytoplankton community structure}

There were significant effects from interactions between carbon and nutrients ( $p=0.003)$, carbon and temperature $(p<0.001)$, and carbon and light $(p=0.006)$ on total phytoplankton biomass at the end of the experiments. Permutational multivariate analysis of variance did not reveal any change in community composition under DOC addition alone, neither in the dark nor in the light.

However, ADONIS analyses showed that the interaction between DOC and nutrients led to significant differences in community structure under the different carbon*nutrients treatments, both in light $\left(r^{2}=0.54, F=5.4, p=0.001\right)$ and in dark conditions $\left(r^{2}=0.30\right.$, $F=1.9, p=0.006)$. Moreover, significant differences in community structure were also detected under the different DOC*temperature conditions, both in light $\left(r^{2}=0.51, F=4.7, p=0.001\right)$ and in dark conditions $\left(r^{2}=0.41, F=3.2, p=0.001\right.$; Table S3). 


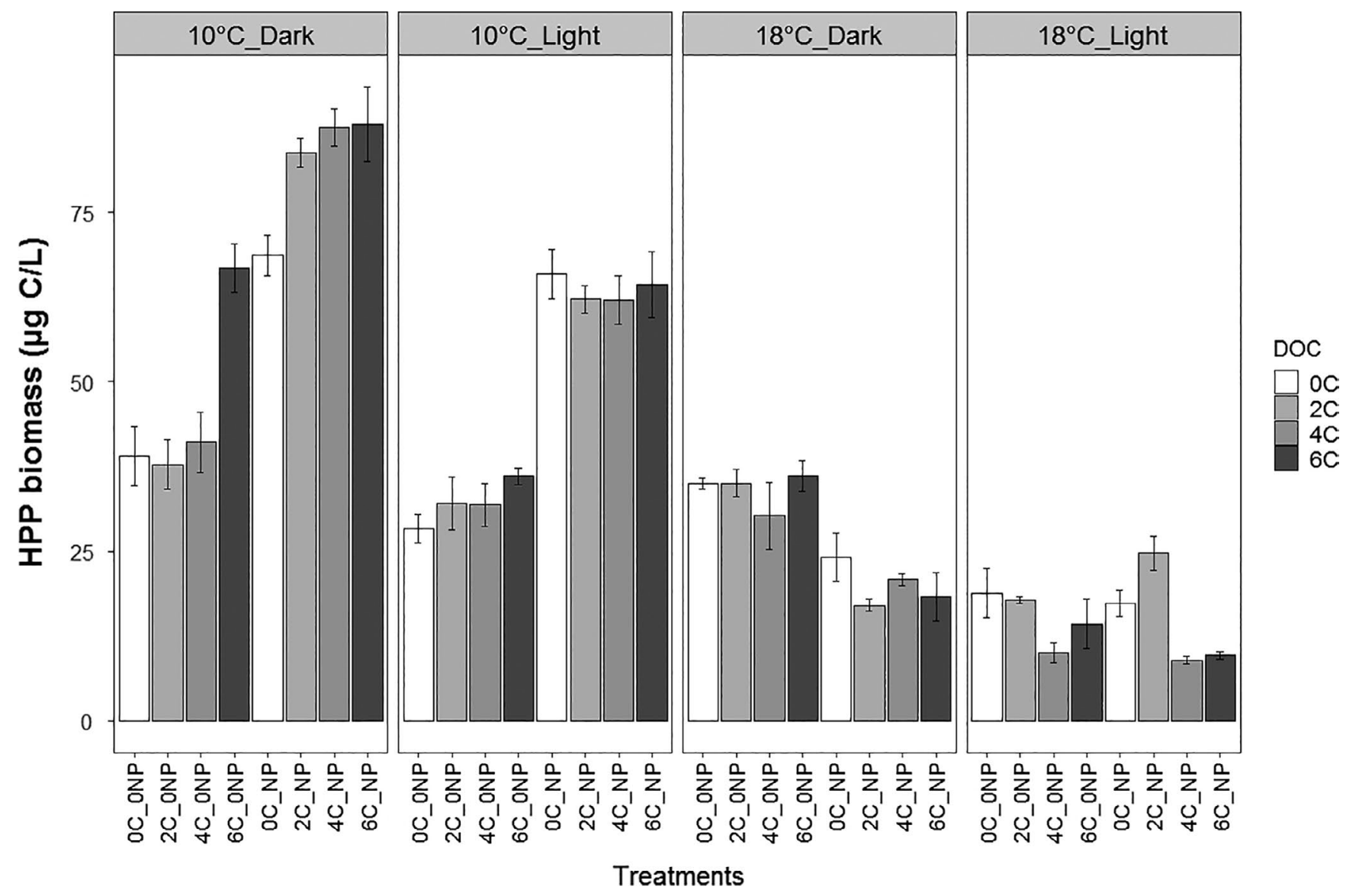

FIGURE 2 Heterotrophic prokaryotic plankton (HPP) biomass at the end of experiments. Biomass is shown for each dissolved organic carbon (DOC)*nutrient treatment under the four temperature*light conditions. Error-bars represent standard error $(n=3)$

At the end of the experiments, five phytoplankton groups accounted for $94 \%$ of differences in community structure observed with increasing DOC (SIMPER analysis): chrysophytes (37\%), picocyanobacteria (27\%), diatoms (19\%), cyanobacteria $>2 \mu \mathrm{m}(5 \%)$, and dinoflagellates (6\%). Concerning the size of the two groups of cyanobacteria, the calculated and measured lengths were highly different between the groups: the mean size of the cyanobacteria $>2 \mu \mathrm{m}$ was $5.04 \pm 0.86 \mu \mathrm{m}$, and the mean size of the picocyanobacteria was $1.5 \pm 0.03 \mu \mathrm{m}$ (data not shown).

Interactions between carbon and nutrients $(p<0.001)$, carbon and temperature $(p<0.001)$, and carbon and light $(p<0.001)$ were shown at the end of the experiments to have significantly affected picophytoplankton biomass, mainly composed of picocyanobacteria (Table S4; Figure S1). Moreover, each interaction between DOC and temperature, light, and nutrients at the 10th experimental day was representative of the other experimental days. The addition of DOC had a negative effect on picocyanobacteria biomass in all conditions of temperature*light, except in the $10^{\circ} \mathrm{C}_{-}$dark condition (Figure 6). In the $10^{\circ} \mathrm{C}$ light condition, picocyanobacteria biomass decreased with DOC addition only when nutrients were added to the microcosms (NP). In the $18^{\circ} \mathrm{C}_{-}$dark and $18^{\circ} \mathrm{C}$ _light conditions, picocyanobacteria biomass decreased with DOC addition at $4 \mathrm{C}$ and $6 \mathrm{C}$ in both NP and ONP treatments.
For the mixotrophic taxa, DOC addition had a positive effect on the relative biomass of mixotrophic phytoplankton, depending on taxonomic groups, conditions of temperature*light, and nutrient addition. The relative biomass of chrysophytes increased with DOC addition in the $10^{\circ} \mathrm{C}$ _light condition in the NP treatments. The relative biomass of cryptophytes increased weakly with DOC addition in the $18^{\circ} \mathrm{C}$ _dark condition at $6 \mathrm{C}$ compared to DOC-controls, in both ONP and NP treatments (Figure S2). The relative biomass of dinoflagellates increased weakly with $\mathrm{DOC}$ addition in the $18^{\circ} \mathrm{C}$ _dark condition in ONP treatments. Finally, the relative biomass of cyanobacteria $>2 \mu \mathrm{m}$ increased with DOC addition when nutrients were added to the microcosms, in all temperature*light conditions except the $10^{\circ} \mathrm{C} \_$dark condition.

\section{4 | DISCUSSION}

The ablation phase is a crucial period in the functioning of high altitude lakes (Felip et al., 2002), because allochthonous inputs can directly affect the food web (Kissman et al., 2017) and therefore govern summer plankton communities. This study sought to assess how planktonic organisms respond to the joint addition of DOC and nutrients during the winter ablation phase in a high-altitude lake. We 

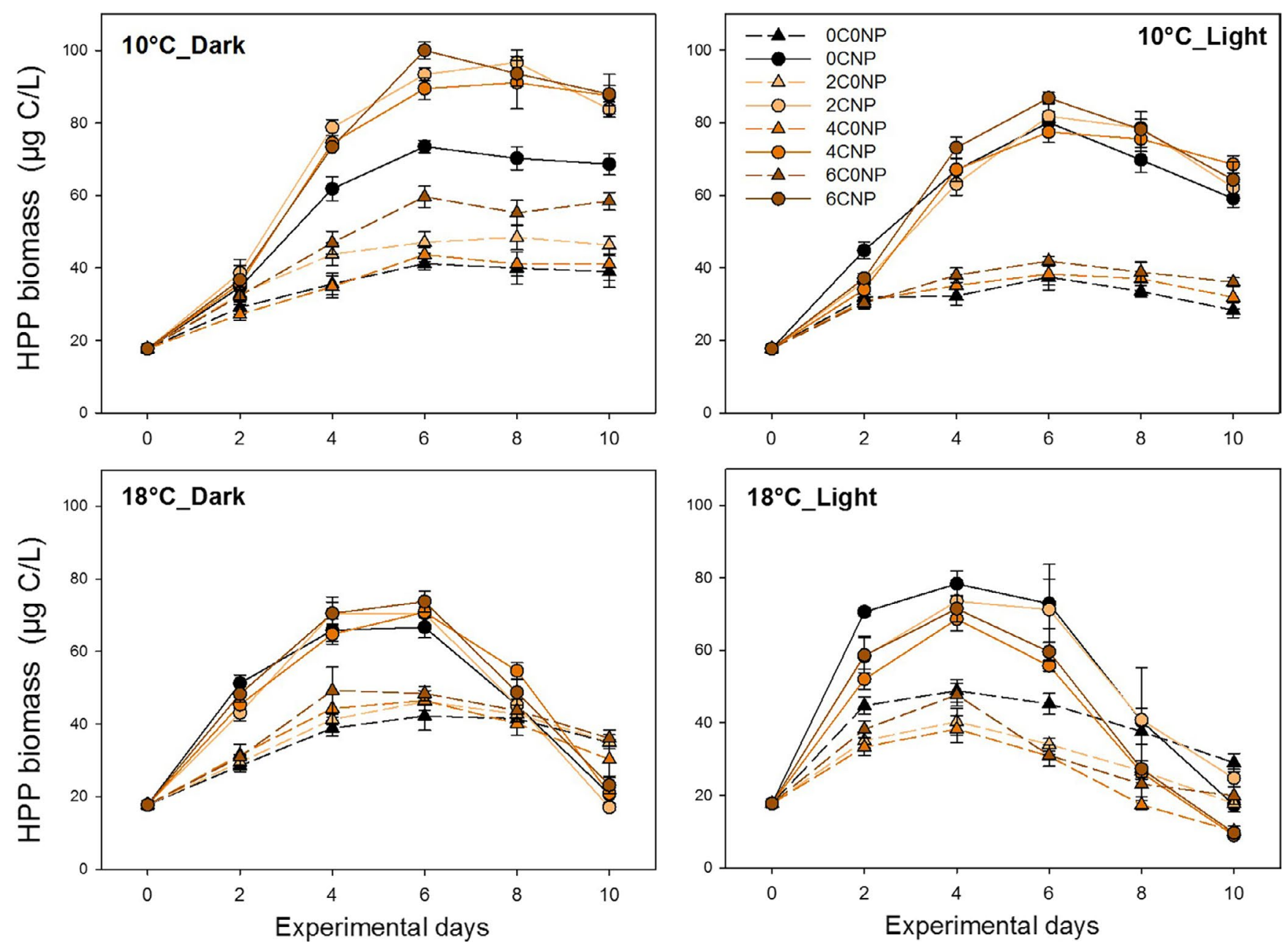

FIGURE 3 Heterotrophic prokaryotic plankton (HPP) biomass per experimental day. Biomass is shown for each dissolved organic carbon $(\mathrm{DOC})^{*}$ nutrient treatment under the four temperature*light conditions. Error-bars represent standard error $(n=3)$

specifically used a multifactorial experimental design to focus on the phytoplankton-bacterioplankton relationship.

\subsection{DOC and nutrient additions in heterotrophic dark conditions}

\subsection{1 | HPP limitation and top-down control regulation}

At the end of the experiments, glucose was consumed in the dark conditions, and more glucose was consumed when nutrients and glucose were added together. Moreover, we found an effect of interaction between DOC and nutrients on HPP biomass. At $10^{\circ} \mathrm{C}$, this interactive effect resulted in a higher HPP biomass when nutrients and DOC were added together than under single additions of DOC or nutrients, evidence of co-limitation of HPP by C, N, and P. Several previous studies also deduced that there was co-limitation by nutrients and carbon in microbial communities of oligotrophic lakes (Vidal et al., 2011), finding stronger responses to combined resources than to single-nutrient additions. Particularly in arctic and alpine lakes, bacterial growth appears to be highly limited by low natural concentrations of inorganic nutrients and organic carbon (Bertoni et al., 2008; Granéli et al., 2004).

By contrast, we did not observe any positive effect of DOC additions on HPP biomass in our microcosms at $18^{\circ} \mathrm{C}$ in the dark conditions, neither when added alone nor when combined with nutrients. Ciliate abundance in our microcosms was stimulated by DOC addition at $18^{\circ} \mathrm{C}$, especially under combined additions of DOC and nutrients. The strong decline in HPP biomass from the 6th day until the end of the experiments at $18^{\circ} \mathrm{C}$ further supports increased predatory pressure from ciliate development in our microcosms. Therefore, the observed HPP response to $\mathrm{DOC}$ additions at $18^{\circ} \mathrm{C}$ was probably the result of strong predation by ciliates. Ciliates are acknowledged to be major consumers of bacteria (Ameryk et al., 2005). In earlier mesocosm experiments, flagellates and ciliates were found to increase following DOC additions (Blomqvist et al., 2001) via a transfer of bacterial production up to these predators. Our findings support the idea that the presence of ciliates acts as a major control of HPP biomass. Moreover, the magnitude of the predatory control increased 


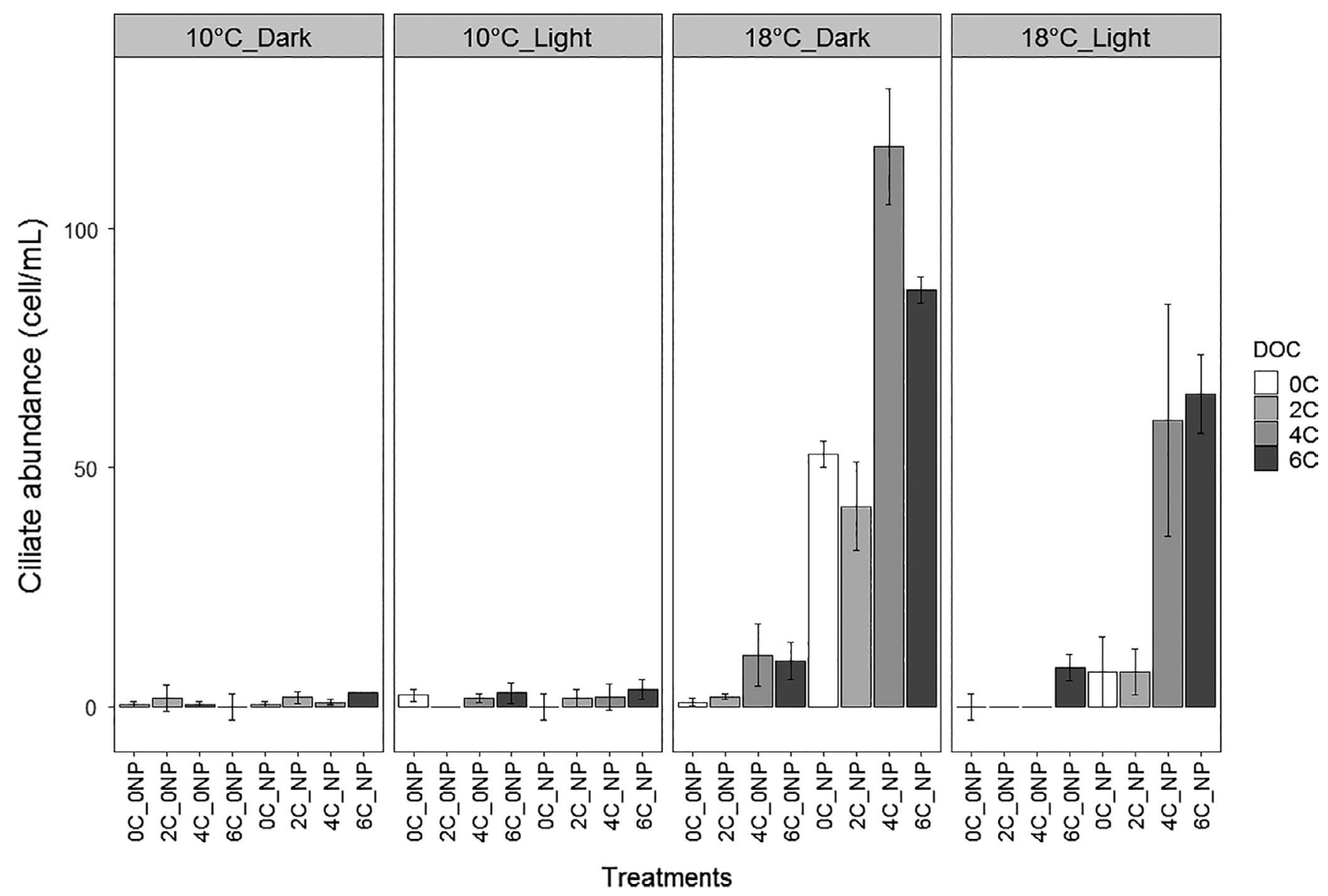

FIGURE 4 Ciliate abundances at the end of experiments. Abundances are shown for each dissolved organic carbon (DOC)*nutrient treatment under the four temperature*light conditions. Error-bars represent standard error $(n=3)$

substantially with changing environmental conditions, and overtook the bottom-up effect of DOC and nutrients on HPP biomass.

\subsection{2 | Phytoplankton response to DOC and nutrients in the dark}

Both chlorophyll and phytoplankton biomass were substantially lower in the dark, indicating a strong reduction of phytoplanktonic influence in these experimental conditions. Due to this very low biomass, we did not observe a clear response to the DOC additions in the dark from either mixotroph or autotroph phytoplankton. There was only a slight tendency to increased biomass of cyanobacteria $>2 \mu \mathrm{m}$ and of cryptophytes biomass under DOC and nutrient additions at $18^{\circ} \mathrm{C}$. Although weak, this tendency confirms that cryptophytes are capable of prey ingestion in darkness (McKie-Krisberg et al., 2015), considered by several studies as a possible adaptation to permanent ice-cover in Antarctic lakes (Marshall \& Laybourn-Parry, 2002). Moreover, even though cyanobacteria $>2 \mu \mathrm{m}$ are considered strictly photoautotrophic in freshwater (Reynolds, 2006), glucose assimilation has been observed in some filamentous species in a deep mesotrophic perialpine lake (Zotina et al., 2003) and in several genera of cyanobacteria in a Siberian saline lake (Quesada et al., 2002). Our results suggest that unicellular cyanobacteria $>2 \mu \mathrm{m}$ could also have played a role in glucose consumption in the dark in our microcosms.

Thus, contrary to our expectations, we found that mixotrophs were not particularly favoured by DOC additions in the dark and that bacterivory by mixotrophs had only a minor impact on the HPP response to DOC addition. Mixotrophy is known to be an advantageous strategy in light-limiting and nutrient-limiting environments, despite a higher energetic cost compared to the obligate autotrophic or heterotrophic metabolism (Mitra et al., 2014). Acquiring carbon and/or mineral nutrients from bacterial prey allows mixotrophs to eliminate their main competitors for these nutrients, called the eating your competitor strategy by Thingstad et al. (1996). However, it was also experimentally demonstrated that mixotrophic bacterivory on picoplankton was light-dependent (Fischer et al., 2017). This dependency has been interpreted as a need for energetic photosynthesis to support phagotrophy (Li et al., 2000).

Overall, DOC additions stimulated HPP biomass in the dark, particularly when combined with addition of nutrients because of the co-limitation of HPP by C, N, and P. However, our results did not confirm our hypothesis regarding mixotrophic phytoplankton. When the influence of commensalistic and competitive interactions between phytoplankton and bacteria were reduced, ciliate predatory control was the major control of the HPP response to DOC addition. 


\subsection{DOC and nutrient additions in light conditions}

\subsection{1 | Diversification of top-down controls in the light}

As in the dark conditions, HPP biomass increased only at $10^{\circ} \mathrm{C}$ with DOC additions, but only when DOC was added alone. Moreover, the increase of ciliates at $18^{\circ} \mathrm{C}$ and the decrease of HPP biomass from the sixth day until the end of the experiments at $18^{\circ} \mathrm{C}$ suggested the same predatory control by ciliates over HPP in the light conditions. Multivariate analyses also revealed significant effects on the phytoplankton community from interactions between the DOC*nutrients treatments and between the DOC*temperature treatments. These interactive effects resulted in increased biomass of chrysophytes after combined DOC and nutrient addition at $10^{\circ} \mathrm{C}$ alone.

Our results reflected a diversification of top-down control in the light conditions, with potential ingestion of HPP by mixotrophs at $10^{\circ} \mathrm{C}$ under combined additions of DOC and nutrients. In the light conditions, mixotrophic phytoplankton and ciliates competed for the same prey in our microcosms. Previous studies reported competition between mixotroph and heterotrophic bacterivores for prey in the light (Fischer et al., 2017). Although temperature optima differ between species, most ciliates tolerate a relatively wide range of temperatures, with high growth rates at high temperatures (Weisse, 2006). Moreover, the metabolic theory of ecology predicts that the heterotrophic metabolism will respond more strongly to rising temperature than the autotrophic metabolism (Rose \& Caron, 2007). Our results show that DOC additions stimulated the mixotrophic strategy of eating your competitor at $10^{\circ} \mathrm{C}$ when nutrients were added to the microcosms, while prey ingestion by ciliates replaced ingestion by mixotrophs at a higher temperature.

\subsubsection{Competition processes with autotrophs}

We found a strong decrease in picocyanobacteria biomass with DOC additions in the light, except at $10^{\circ} \mathrm{C}$ without nutrients. Previous studies reported a competitive advantage of heterotrophic bacteria over picocyanobacteria, especially after carbon inputs (Drakare, 2002; Liao et al., 2019). We therefore suggest that the observed decrease in picocyanobacteria could be due to competition between HPP and picocyanobacteria for nutrients. Added to the competition with HPP, picocyanobacteria can also suffer predation by mixotrophs and ciliates. In shallow oligotrophic lakes, ingestion of picocyanobacteria by mixotrophic flagellates was recently observed (Gerea et al. 2019), notably by chrysophytes in subalpine lakes (Weisse \& Moser, 2020).

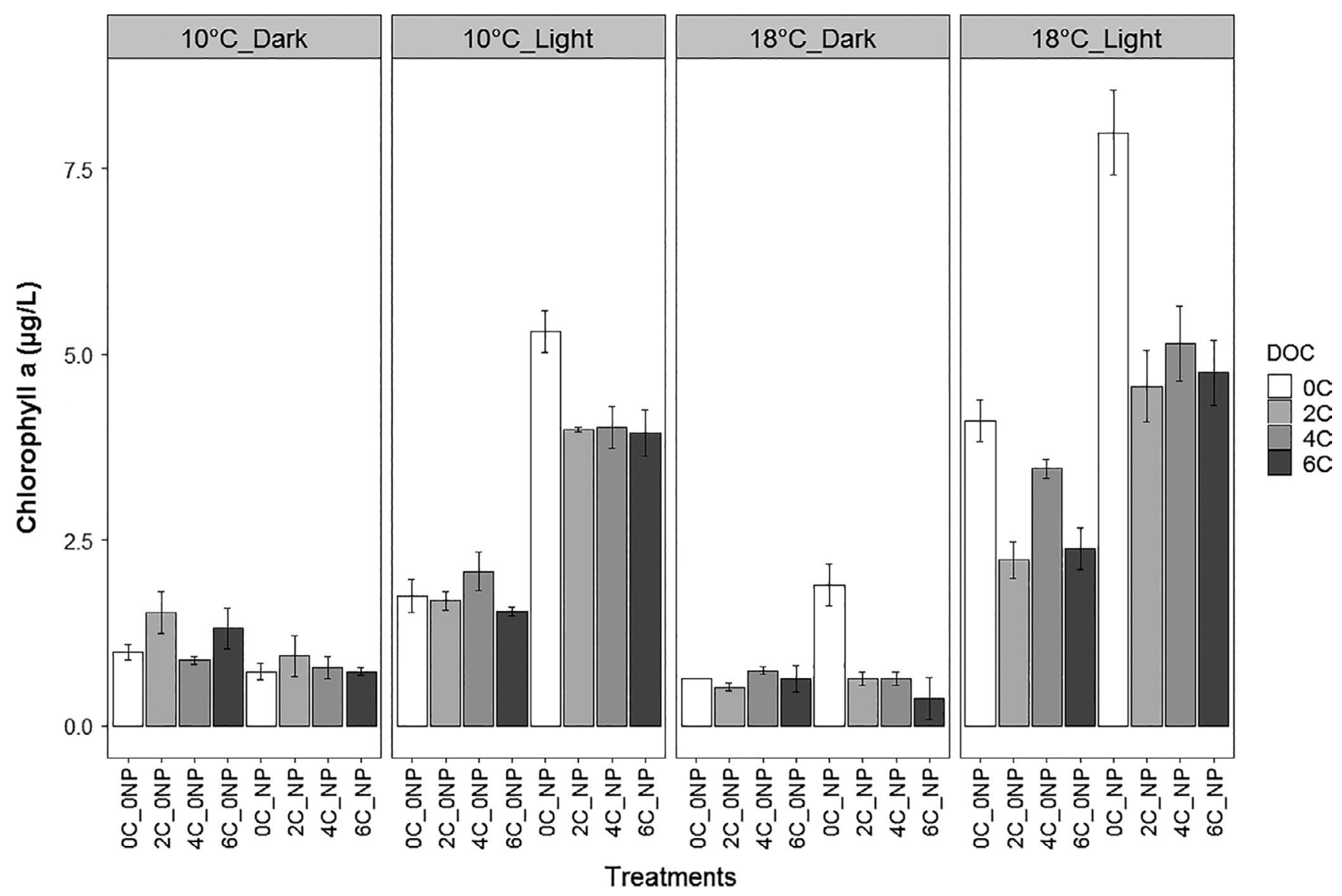

FIGURE 5 Chlorophyll biomass at the end of experiments. Concentrations are shown for each dissolved organic carbon (DOC)*nutrient treatment under the four temperature*light conditions. Error-bars represent standard error $(n=3)$ 

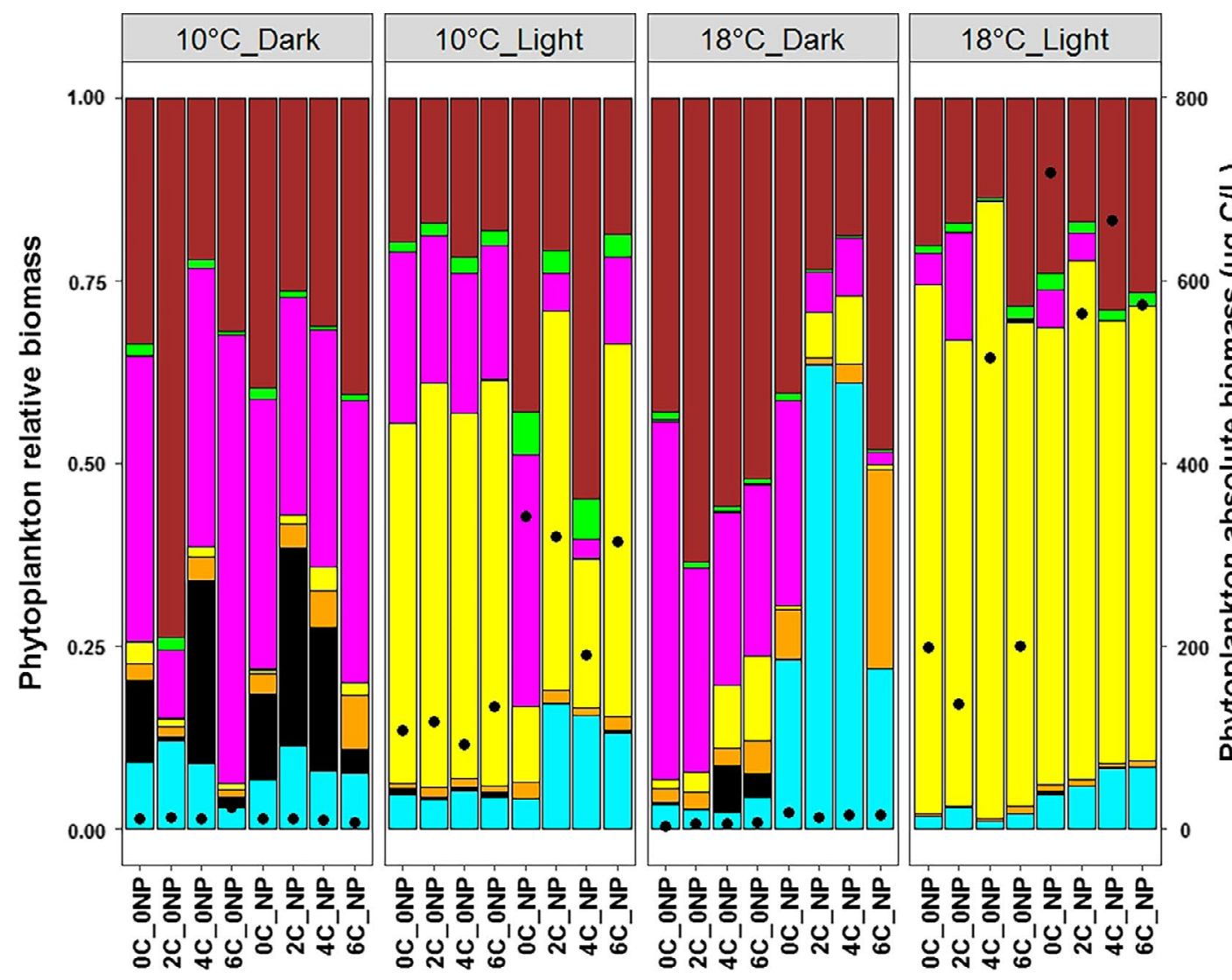

800

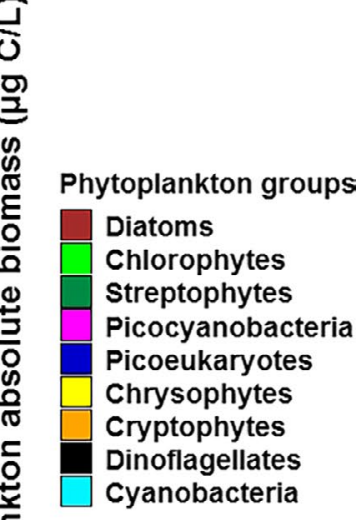

FIGURE 6 Phytoplankton groups relative biomass and total absolute biomass (black points) at the end of experiments. Biomass is shown for each dissolved organic carbon*nutrient treatment under the four temperature*light conditions

Unfortunately, our experiments did not enable us to determine the proportions of the decrease in picocyanobacteria explained by competition with HPP and by predation by bacterivores.

Contrary to the picocyanobacteria, the biomass of the cyanobacteria $>2 \mu \mathrm{m}$ increased with combined additions of DOC and nutrients in the light. As in the dark, this increase indicates that the cyanobacteria $>2 \mu \mathrm{m}$ were capable of carbon assimilation and depended on a sufficient stoichiometric C: NP ratio to develop in the light conditions.

Overall, DOC additions in the light stimulated the biomass of HPP and mixotrophs, and predation by mixotrophs acted as a strong top-down control of HPP biomass at $10^{\circ} \mathrm{C}$. While DOC addition decreased autotrophic picocyanobacteria, the proportions of this decrease explained by competition with HPP and by predation by ciliates and mixotrophs could not be determined from our experiments. As in the dark, the predatory control exerted by ciliates on HPP biomass was the major control at the higher temperature.

\section{3 | Primarily nutrient limitation and commensalistic interaction}

We found that DOC concentrations increased in the DOC-control treatments in the light conditions, but not in the dark, which indicates two indirect results: (1) phytoplankton-derived carbon was produced in the light; and (2) control by phytoplankton-derived carbon was severely limited in the dark at the end of the experiments. Moreover, HPP biomass in the dark conditions revealed that HPP were able to develop with added nutrients alone, evidence of limitation primarily by $\mathrm{N}$ and $\mathrm{P}$ of the HPP in our microcosms. Due to the generally low DOC concentrations in high-altitude lakes, heterotrophic bacteria are known to be primarily carbon-limited in these environments (Carrillo et al., 2002; Durán et al., 2016; MedinaSánchez et al., 2010). Nevertheless, limitation primarily by nutrients and co-limitation by $\mathrm{C}$ of bacteria was previously observed in an oligotrophic mountain lake (Dorado-García et al., 2014). This pattern of co-limitation was explained by the autotrophic nature of the ecosystem, where carbon derived from phytoplankton was sufficient to support bacterial demands. In our experiments, while the initial phytoplankton biomass was slightly smaller than the HPP biomass, it may have been sufficient to generate limitation of HPP primarily by $\mathrm{N}$ and $\mathrm{P}$ and co-limitation by $\mathrm{C}$. Despite stronger limitation by nutrients than by carbon, an increase in HPP biomass was observed in our microcosms after DOC additions. This could be interpreted as a release from HPP dependency on photosynthetic carbon excreted by phytoplankton, i.e. a decrease in commensalistic interactions between HPP and phytoplankton. 


\section{4 | Ecological implications}

Our results support previous findings that DOC inputs can greatly alter the food web in high-altitude lakes (Kissman et al., 2017), particularly if they occur during the ablation phase. Our results suggest that DOC inputs during the ablation phase, depending on nutrient limitation, may rapidly alter the trophic interactions between heterotrophic bacteria and phytoplankton. These changes are likely to involve decreased commensalistic interactions between bacteria and phytoplankton but increased competition with autotrophic picocyanobacteria, and an increase and diversification of predatory top-down controls over bacteria. Since the winter communities constitute the inoculum of the summer succession in high-altitude lakes (Adrian et al., 1999), rapid changes in trophic relationships between bacteria and phytoplankton can have major repercussions on the general functioning of lakes. While bacteria would benefit more than phytoplankton from labile DOC inputs in a future scenario of global change, higher predatory control over bacteria is also expected. Thus, our findings support a future scenario of global change involving modifications in the balance of heterotrophic versus autotrophic processes toward higher heterotrophy during the ablation phase in high-altitude lakes. The predicted change will vary according to: (1) the characteristics of the dissolved organic matter, i.e. nutrient content, lability of the carbon source, and proportion of humic coloured substances; (2) type of top-down control, such as predation by zooplankton or ciliates; and (3) the composition of phytoplankton assemblages, including the proportion of mixotrophic phytoplankton.

\section{ACKNOWLEDGMENTS}

We are grateful to Eric Meineri and to members of the French Biodiversity Office for their help in the field. DOC analyses were carried out by the Mediterranean Institute of Oceanography. Data used in this study were partly produced through the technical facilities of the Biological and Chemical Analysis (IMBE, Marseille) by David Brinvillier. We thank Marjorie Sweetko for improving the English of this manuscript. Flavia Dory received a PhD fellowship from the Ministère de l'Enseignement Supérieur et de la Recherche and this paper is part of her Ph.D.

\section{CONFLICT OF INTEREST}

The authors declare no conflicts of interest.

\section{DATA AVAILABILITY STATEMENT}

The datasets generated and analysed during the current study are available from the corresponding author on reasonable request.

\section{ORCID}

Flavia Dory (iD https://orcid.org/0000-0002-5083-0737 Laurent Cavalli iD https://orcid.org/0000-0001-9151-3247 Evelyne Franquet iD https://orcid.org/0000-0002-7779-772X Magalie Claeys-Bruno iD https://orcid.org/0000-0001-7168-2190 Benjamin Misson iD https://orcid.org/0000-0002-4107-0916 Thierry Tatoni iD https://orcid.org/0000-0002-2557-4444 Céline Bertrand iD https://orcid.org/0000-0003-3085-3234

\section{REFERENCES}

Adrian, R., Walz, N., Hintze, T., Hoeg, S., \& Rusche, R. (1999). Effects of ice duration on plankton succession during spring in a shallow polymictic lake. Freshwater Biology, 41(3), 621-634. https://doi. org/10.1046/j.1365-2427.1999.00411.x

Ameryk, A., Podgorska, B., \& Witek, Z. (2005). The dependence between bacterial production and environmental conditions in the Gulf of Gdańsk. Oceanologia, 47(1), 27-45.

Anderson, M. J., Ellingsen, K. E., \& McArdle, B. H. (2006). Multivariate dispersion as a measure of beta diversity. Ecology Letters, 9(6), 683693. https://doi.org/10.1111/j.1461-0248.2006.00926.x

Auer, I., Böhm, R., Jurkovic, A., Lipa, W., Orlik, A., Potzmann, R., ... Nieplova, E. (2007). HISTALP-Historical instrumental climatological surface time series of the Greater Alpine Region. International Journal of Climatology, 27(1), 17-46. https://doi.org/10.1002/joc.1377

Battarbee, R. W., Kernan, M., \& Rose, N. (2009). Threatened and stressed mountain lakes of Europe: Assessment and progress. Aquatic Ecosystem Health \& Management, 12(2), 118-128. https://doi. org/10.1080/14634980902905742

Bergström, A. K., Jonsson, A., \& Jansson, M. (2008). Phytoplankton responses to nitrogen and phosphorus enrichment in unproductive Swedish lakes along a gradient of atmospheric nitrogen deposition. Aquatic Biology, 4, 55-64. https://doi.org/10.3354/ab00099

Bertoni, R., Callieri, C., Balseiro, E., \& Modenutti, B. (2008). Susceptibility of bacterioplankton to nutrient enrichment of oligotrophic and ultraoligotrophic lake waters. Journal of Limnology, 67(2), 120-127. https://doi.org/10.4081/jlimnol.2008.120

Blomqvist, P., Jansson, M., Drakare, S., Bergström, A. K., \& Brydsten, L. (2001). Effects of additions of DOC on pelagic biota in a clearwater system: Results from a whole lake experiment in northern Sweden. Microbial Ecology, 42(3), 383-394. https://doi.org/10.1007/s0024 80000101

Box, G. E., Hunter, W. H., \& Hunter, S. (1978). Statistics for experimenters, Vol. 664. John Wiley and Sons.

Carney, R. L., Seymour, J. R., Westhorpe, D., \& Mitrovic, S. M. (2016). Lotic bacterioplankton and phytoplankton community changes under dissolved organic-carbon amendment: Evidence for competition for nutrients. Marine and Freshwater Research, 67(9), 1362-1373. https://doi.org/10.1071/MF15372

Carrillo, P., Medina-Sánchez, J. M., \& Villar-Argaiz, M. (2002). The interaction of phytoplankton and bacteria in a high mountain lake: Importance of the spectral composition of solar radiation. Limnology and Oceanography, 47(5), 1294-1306. https://doi.org/10.4319/ lo.2002.47.5.1294

Catalan, J., Camarero, L., Felip, M., Pla, S., Ventura, M., Buchaca, T., ... de Quijano, D. D. (2006). High mountain lakes: Extreme habitats and witnesses of environmental changes. Limnética, 25(1-2), 551-584.

Deininger, A., Faithfull, C. L., \& Bergström, A. K. (2017). Nitrogen effects on the pelagic food web are modified by dissolved organic carbon. Oecologia, 184(4), 901-916. https://doi.org/10.1007/s0044 2-017-3921-5

Dorado-García, I., Medina-Sánchez, J. M., Herrera, G., Cabrerizo, M. J., \& Carrillo, P. (2014). Quantification of carbon and phosphorus co-limitation in bacterioplankton: New insights on an old topic. PLoS One, 9(6), e99288. https://doi.org/10.1371/journ al.pone.0099288

Drakare, S. (2002). Competition between picoplanktonic cyanobacteria and heterotrophic bacteria along crossed gradients of glucose and phosphate. Microbial Ecology, 44(4), 327-335. https://doi. org/10.1007/s00248-002-1013-4

Dubourg, P., North, R. L., Hunter, K., Vandergucht, D. M., Abirhire, O., Silsbe, G. M., ... Hudson, J. J. (2015). Light and nutrient co-limitation of phytoplankton communities in a large reservoir: Lake Diefenbaker, Saskatchewan, Canada. Journal of Great Lakes Research, 41, 129-143. https://doi.org/10.1016/j.jglr.2015.10.001 
Ducklow, H. (2000). Bacterial production and biomass in the oceans. Microbial Ecology of the Oceans, 1, 85-120.

Durán, C., Medina-Sánchez, J. M., Herrera, G., \& Carrillo, P. (2016). Changes in the phytoplankton-bacteria coupling triggered by joint action of UVR, nutrients, and warming in Mediterranean highmountain lakes. Limnology and Oceanography, 61(2), 413-429. https:// doi.org/10.1002/Ino.10204

Egli, T., \& Zinn, M. (2003). The concept of multiple-nutrient-limited growth of microorganisms and its application in biotechnological processes. Biotechnology Advances, 22(1), 35-43. https://doi. org/10.1016/j.biotechadv.2003.08.006

Ejarque, E., Khan, S., Steniczka, G., Schelker, J., Kainz, M. J., \& Battin, T. J. (2018). Climate-induced hydrological variation controls the transformation of dissolved organic matter in a subalpine lake. Limnology and Oceanography, 63(3), 1355-1371. https://doi.org/10.1002/Ino.10777

Elser, J. J., Kyle, M., Steger, L., Nydick, K. R., \& Baron, J. S. (2009). Nutrient availability and phytoplankton nutrient limitation across a gradient of atmospheric nitrogen deposition. Ecology, 90(11), 3062-3073. https://doi.org/10.1890/08-1742.1

Felip, M., Wille, A., Sattler, B., \& Psenner, R. (2002). Microbial communities in the winter cover and the water column of an alpine lake: System connectivity and uncoupling. Aquatic Microbial Ecology, 29, 123-134. https://doi.org/10.3354/ame029123

Fischer, R., Giebel, H.-A., Hillebrand, H., \& Ptacnik, R. (2017). Importance of mixotrophic bacterivory can be predicted by light and loss rates. Oikos, 126(5), 713-722. https://doi.org/10.1111/oik.03539

Fischer, R., Giebel, H.-A., \& Ptacnik, R. (2017). Identity of the limiting nutrient ( $\mathrm{N}$ vs. P) affects the competitive success of mixotrophs. Marine Ecology Progress Series, 563, 51-63. https://doi.org/10.3354/meps1 1968

Gerea, M., Queimalinos, C., \& Unrein, F. (2019). Grazing impact and prey selectivity of picoplanktonic cells by mixotrophic flagellates in oligotrophic lakes. Hydrobiologia, 831(1), 5-21. https://doi.org/10.1007/ s10750-018-3610-3

González-Olalla, J. M., Medina-Sánchez, J. M., Lozano, I. L., Villar-Argaiz, M., \& Carrillo, P. (2018). Climate-driven shifts in algal-bacterial interaction of high-mountain lakes in two years spanning a decade. Scientific Reports, 8(1), 1-12. https://doi.org/10.1038/s41598-01828543-2

Granéli, W., Bertilsson, S., \& Philibert, A. (2004). Phosphorus limitation of bacterial growth in high Arctic lakes and ponds. Aquatic Sciences, 66(4), 430-439. https://doi.org/10.1007/s00027-004-0732-7

Hitchcock, J. N., \& Mitrovic, S. M. (2013). Different resource limitation by carbon, nitrogen and phosphorus between base flow and high flow conditions for estuarine bacteria and phytoplankton. Estuarine, Coastal and Shelf Science, 135, 106-115. https://doi.org/10.1016/j. ecss.2013.05.001

Hitchcock, J. N., Mitrovic, S. M., Kobayashi, T., \& Westhorpe, D. P. (2010). Responses of estuarine bacterioplankton, phytoplankton and zooplankton to dissolved organic carbon (DOC) and inorganic nutrient additions. Estuaries and Coasts, 33(1), 78-91. https://doi. org/10.1007/s12237-009-9229-x

IPCC. (2013). Climate change 2013: The physical science basis. Contribution of working Group I to the fifth assessment report of the intergovernmental panel on climate change. GIEC.

Izaguirre, I., Allende, L., \& Romina Schiaffino, M. (2020). Phytoplankton in Antarctic lakes: Biodiversity and main ecological features. Hydrobiologia, 848, 177-207. https://doi.org/10.1007/s10750-02004306-x

Jacquemin, C. (2019). Vulnerability of high altitude lakes to climate change. Aix-Marseille.

Jacquemin, C., Bertrand, C., Oursel, B., Thorel, M., Franquet, E., \& Cavalli, L. (2018). Growth rate of alpine phytoplankton assemblages from contrasting watersheds and $\mathrm{N}$-deposition regimes exposed to nitrogen and phosphorus enrichments. Freshwater Biology, 63(10), 1326-1339. https://doi.org/10.1111/fwb.13160

Jansson, M., Bergström, A.-K., Blomqvist, P., \& Drakare, S. (2000). Allochthonous organic carbon and phytoplankton/bacterioplankton production relationships in lakes. Ecology, 81(11), 3250-3255.

Jansson, M., Bergström, A.-K., Blomqvist, P., Isaksson, A., \& Jonsson, A. (1999). Impact of allochthonous organic carbon on microbial food web carbon dynamics and structure in Lake Örträsket. Archiv Für Hydrobiologie, 144(4), 409-428. https://doi.org/10.1127/archivhydrobiol/144/1999/409

Karlsson, J. (2001). Pelagic energy mobilization and carbon dioxide balance in subarctic lakes in Northern Sweden (p. 15). Umeå University. http:// urn.kb.se/resolve?urn=urn:nbn:se:polar:diva-5948

Kissman, C. E. H., Williamson, C. E., Rose, K. C., \& Saros, J. E. (2017). Nutrients associated with terrestrial dissolved organic matter drive changes in zooplankton:phytoplankton biomass ratios in an alpine lake. Freshwater Biology, 62(1), 40-51. https://doi.org/10.1111/ fwb.12847

Laurion, I., Ventura, M., Catalan, J., Psenner, R., \& Sommaruga, R. (2000). Attenuation of ultraviolet radiation in mountain lakes: Factors controlling the among- and within-lake variability. Limnology and Oceanography, 45(6), 1274-1288. https://doi.org/10.4319/ lo.2000.45.6.1274

Leydecker, A., Sickman, J. O., \& Melack, J. M. (2001). Spatial scaling of hydrological and biogeochemical aspects of high-altitude catchments in the Sierra Nevada, California, U.S.A. Arctic, Antarctic, and Alpine Research, 33(4), 391-396. https://doi.org/10.1080/15230 430.2001.12003446

Li, A., Stoecker, D. K., \& Coats, D. W. (2000). Mixotrophy in Gyrodinium galatheanum (Dinophyceae): Grazing responses to light intensity and inorganic nutrients*. Journal of Phycology, 36(1), 33-45. https://doi. org/10.1046/j.1529-8817.2000.98076.x

Liao, J., Xu, J., Yuan, X., Liang, Y., Guo, Y., Zhou, W., ... Long, A. (2019). Interactive effects of ultraviolet radiation and dissolved organic carbon on phytoplankton growth and photosynthesis in Sanya Bay, Northern South China Sea. Ocean Science Journal, 54(4), 581-593. https://doi.org/10.1007/s12601-019-0033-7

Linacre, L., Lara-Lara, R., Camacho-lbar, V., Herguera, J. C., BazánGuzmán, C., \& Ferreira-Bartrina, V. (2015). Distribution pattern of picoplankton carbon biomass linked to mesoscale dynamics in the southern Gulf of Mexico during winter conditions. Deep Sea Research Part I: Oceanographic Research Papers, 106, 55-67. https://doi. org/10.1016/j.dsr.2015.09.009

Marshall, W., \& Laybourn-Parry, J. (2002). The balance between photosynthesis and grazing in Antarctic mixotrophic cryptophytes during summer. Freshwater Biology, 47(11), 2060-2070. https://doi. org/10.1046/j.1365-2427.2002.00950.x

McKie-Krisberg, Z. M., Gast, R. J., \& Sanders, R. W. (2015). Physiological responses of three species of antarctic mixotrophic phytoflagellates to changes in light and dissolved nutrients. Microbial Ecology, 70(1), 21-29. https://doi.org/10.1007/s00248-014-0543-x

Medina-Sánchez, J. M., Carrillo, P., Delgado-Molina, J. A., Bullejos, F. J., \& Villar-Argaiz, M. (2010). Patterns of resource limitation of bacteria along a trophic gradient in Mediterranean inland waters. FEMS Microbiology Ecology, 74(3), 554-565. https://doi. org/10.1111/j.1574-6941.2010.00969.x

Medina-Sánchez, J. M., Villar-Argaiz, M., \& Carrillo, P. (2004). Neither with nor without you: A complex algal control on bacterioplankton in a high mountain lake. Limnology and Oceanography, 49(5), 1722-1733. https://doi.org/10.4319/lo.2004.49.5.1722

Mitra, A., Flynn, K. J., Burkholder, J. M., Berge, T., Calbet, A., Raven, J. A., ... Zubkov, M. V. (2014). The role of mixotrophic protists in the biological carbon pump. Biogeosciences, 11(4), 995-1005. https://doi. org/10.5194/bg-11-995-2014 
Montgomery, D. C. (2017). Design and analysis of experiments. John Wiley $\&$ Sons.

Moser, K. A., Baron, J. S., Brahney, J., Oleksy, I. A., Saros, J. E., Hundey, E. J., ... Smol, J. P. (2019). Mountain lakes: Eyes on global environmental change. Global and Planetary Change, 178, 77-95. https://doi. org/10.1016/j.gloplacha.2019.04.001

Pernica, P., North, R. L., \& Baulch, H. M. (2017). In the cold light of day: The potential importance of under-ice convective mixed layers to primary producers. Inland Waters, 7(2), 138-150. https://doi. org/10.1080/20442041.2017.1296627

Pinhassi, J., Gómez-Consarnau, L., Alonso-Sáez, L., Sala, M. M., Vidal, M., Pedrós-Alió, C., \& Gasol, J. M. (2006). Seasonal changes in bacterioplankton nutrient limitation and their effects on bacterial community composition in the NW Mediterranean Sea. Aquatic Microbial Ecology, 44(3), 241-252. https://doi.org/10.3354/ame044241

Quesada, A., Jüttner, F., Zotina, T., Tolomeyev, A. P., \& Degermendzhy, A. G. (2002). Heterotrophic capability of a metalimnetic plankton population in saline Lake Shira (Siberia, Khakasia). Aquatic Ecology, 36(2), 219-227. https://doi.org/10.1023/A:1015672800327

Reynolds, C. S. (2006). Ecology of phytoplankton. Cambridge University Press.

Rose, J. M., \& Caron, D. A. (2007). Does low temperature constrain the growth rates of heterotrophic protists? Evidence and implications for algal blooms in cold waters. Limnology and Oceanography, 52(2), 886895. https://doi.org/10.4319/lo.2007.52.2.0886

Sadro, S., \& Melack, J. M. (2012). The effect of an extreme rain event on the biogeochemistry and ecosystem metabolism of an oligotrophic high-elevation lake. Arctic, Antarctic, and Alpine Research, 44(2), 222231. https://doi.org/10.1657/1938-4246-44.2.222

Sadro, S., Sickman, J. O., Melack, J. M., \& Skeen, K. (2018). Effects of climate variability on snowmelt and implications for organic matter in a high-elevation lake. Water Resources Research, 54(7), 4563-4578. https://doi.org/10.1029/2017WR022163

Smiatek, G., Kunstmann, H., \& Senatore, A. (2016). EURO-CORDEX regional climate model analysis for the greater alpine region: Performance and expected future change. Journal of Geophysical Research: Atmospheres, 121(13), 7710-7728. https://doi. org/10.1002/2015JD024727

Soares, A. R. A., Kritzberg, E. S., Custelcean, I., \& Berggren, M. (2018). Bacterioplankton responses to increased organic carbon and nutrient loading in a boreal estuary-Separate and interactive effects on growth and respiration. Microbial Ecology, 76(1), 144-155. https://doi. org/10.1007/s00248-017-1115-7

Thingstad, T. F., Havskum, H., Garde, K., \& Riemann, B. (1996). On the strategy of 'eating your competitor': A mathematical analysis of algal mixotrophy. Ecology, 77(7), 2108-2118. https://doi. org/10.2307/2265705

Utermöhl, H. (1958). Methods of collecting plankton for various purposes are discussed. SIL Communications, 1953-1996, 9(1), 1-38. https://doi. org/10.1080/05384680.1958.11904091

Vidal, L. O., Granéli, W., Daniel, C. B., Heiberg, L., \& Roland, F. (2011). Carbon and phosphorus regulating bacterial metabolism in oligotrophic boreal lakes. Journal of Plankton Research, 33(11), 1747-1756. https://doi.org/10.1093/plankt/fbr059

Weisse, T. (2006). Freshwater ciliates as ecophysiological model organisms-lessons from Daphnia, major achievements, and future perspectives. Archiv Fur Hydrobiologie, 167(1-4), 371-402. https:// doi.org/10.1127/0003-9136/2006/0167-0371

Weisse, T., \& Moser, M. (2020). Light affects picocyanobacterial grazing and growth response of the mixotrophic flagellate Poterioochromonas malhamensis. Journal of Microbiology, 58(4), 268-278. https://doi. org/10.1007/s12275-020-9567-8

Wetzel, R. G., \& Likens, G. E. (2000). Composition and biomass of phytoplankton. In R. G. Wetzel, \& G. E. Likens (Eds.), Limnological analyses (pp. 147-174). Springer. https://doi. org/10.1007/978-1-4757-3250-4_10

Williamson, C. E., Saros, J. E., Vincent, W. F., \& Smold, J. P. (2009). Lakes and reservoirs as sentinels, integrators, and regulators of climate change. Limnology and Oceanography, 54(6part2), 2273-2282. https://doi.org/10.4319/lo.2009.54.6_part_2.2273

Zotina, T., Köster, O., \& Jüttner, F. (2003). Photoheterotrophy and lightdependent uptake of organic and organic nitrogenous compounds by Planktothrix rubescens under low irradiance. Freshwater Biology, 48(10), 1859-1872. https://doi.org/10.1046/j.1365-2427.2003.01134.x

\section{SUPPORTING INFORMATION}

Additional supporting information may be found online in the Supporting Information section.

How to cite this article: Dory F, Cavalli L, Franquet E, et al. Microbial consortia in an ice-covered high-altitude lake impacted by additions of dissolved organic carbon and nutrients. Freshw Biol. 2021;00:1-15. https://doi. org/10.1111/fwb.13781 